\title{
PILED RAFT - AN EFFECTIVE FOUNDATION DESIGN METHOD FOR HIGH-RISE BUILDINGS IN HO CHI MINH CITY, VIET NAM
}

\author{
Ha Tran Quang ${ }^{1}$ *Kamol Amornfa ${ }^{2}$ and Tran Van Tuan ${ }^{3}$ \\ ${ }^{1,2}$ Department of Civil Engineering, Faculty of Engineering at Kamphaeng Saen, Kasetsart University, \\ Thailand; ${ }^{3}$ Department of Civil Engineering, College of Engineering Technology, Can Tho University, Viet \\ Nam.
}

*Corresponding Author, Received: 23 Sept. 2021, Revised: 25 Oct. 2021, Accepted: 21 Nov. 2021

\begin{abstract}
Nowadays, the wave of construction of high-rise buildings, which usually use the concept of piled group foundation in their design, has increased in Ho Chi Minh City as well as other cities in Viet Nam. In this study, settlement, the load shared by the raft, and the behavior of the piled raft were considered via monitoring settlement and the Poulos-Davis-Randolph (PDR) method where the settlement of a varying number of piles, the pile length, and raft embedment were determined. The results of settlement monitoring of a high-rise building in Ho Chi Minh City showed that the foundation design of this building was conservative, with a ratio of allowable-to-actual settlement of 9.3. In the simplified method, the proportion of load share by raft was $2.8 \%$ (which was ignored in the piled foundation concept), with the settlement results being in good agreement with the measurement results. The parametric analysis indicated that the piled spacing/piled diameter was 5 - 7 times the recommended optimum value. Furthermore, increasing the pile length decreased settlement. The pile length was equal to 30 times the pile diameter, which was effective for the settlement ratio. In addition, the raft load share reached $30 \%$ of the applied load when the raft was put in the second layer of stiff-to-very-stiff clay. The study indicated the simplified method was effective for evaluating the preliminary conditions of the foundation, settlement, and that a piled raft was feasible for Ho Chi Minh City's subsoil geology.
\end{abstract}

Keywords: Ho Chi Minh soil condition, Piled raft, High-rise buildings, Monitoring settlement, Load sharing.

\section{INTRODUCTION}

The foundation system must be designed to ensure the structure and support system are stable as a whole and overall stability must be established. There are three popular foundation options to carry the heavy load from a high-rise building. First, a raft foundation is transfers load directly to the soil beneath the structure. Second, the piled foundation transfers the load to the deep soil layer via piles. Finally, a piled raft foundation is an effective method for high-rise buildings by transferring part of the building load directly to the soil beneath the raft via the raft and another part of the building load is transferred by the piles to the deep soil layer.

Raft foundations are used widely in the construction industry, especially for high-rise buildings. In Frankfurt, Germany, there are highrise buildings that were constructed on medium-todense sand or gravel, such as The Commerzbank Tower with a height of $130 \mathrm{~m}$, the twin towers of the Deutsche Bank Building with a height of 157.7 $\mathrm{m}$, and the Frankfurt Büro-Centre Building with a height of $147 \mathrm{~m}$. Average settlement is in the range 150 - $250 \mathrm{~mm}[1]$.

A piled foundation is necessary when the bearing capacity of the subsoil beneath the raft is not high enough to carry the building load. In the piled foundation concept, the piles transfer the entire building load to the deep soil layer where there is sufficient load-bearing capacity. The contribution of the raft in this concept is ignored and the designer will add a factor for safety of 2-5 times in the standard design foundation [2]. Thus, a larger, longer pile size and more piles are requied. However, the contribution of the raft is important when it is combined with the piles, known as the piled raft foundation concept [3-6], where the raft can transfer a part of the building load to the soil below. The proportions of load carried by the raft $(20-40 \%)$ of the total load may be transferred directly to the soil. The piles carry only a part of the building load, which is designed as a reduced settlement $[7,8]$. The contributions of this concept are the interactions between soil-raft, raft-pile, pilepile, and soil-pile [1].

Before 1975, there were few high-rise buildings in Ho Chi Minh City. The wave of construction of residential and commercial high-rise buildings started in the early 1990s when the Land Law was amended [9]. Examples in Ho Chi Minh City are the Saigon Trade Center (37 Ton Duc Thang St) which was the tallest building in 2008 at $145 \mathrm{~m}$. In 2010, the Financial Tower (Bitexco) became the highest building at $262 \mathrm{~m}$. Now, the Vincom Landmark 81 is currently the highest building in Ho Chi Minh and 
in Viet Nam generally, with 81 floors (461 m). In 2010, there were 225 high-rise building projects; almost all of these were concentrated in the center of the city. In later years, high-rise buildings have been constructed in urban areas of the city, such as in the Thu Thiem urban area, Thu Duc City, District 9. The trend in the construction of high-rise buildings will parallel urban area development in the city. The demand for residential, commercial buildings is expected to increase with the economic growth of Ho Chi Minh City, as shown in Fig. 1 and Table 1.

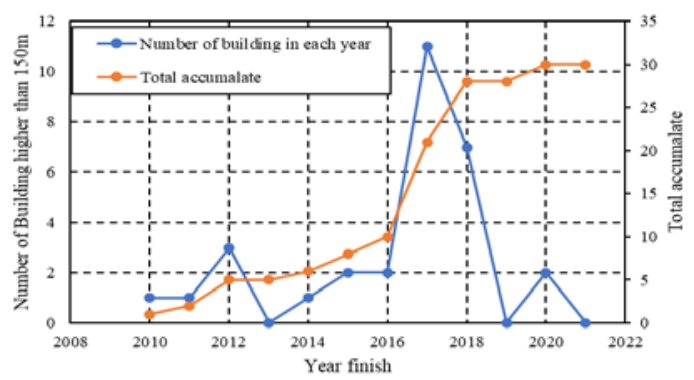

Fig. 1. Growing numbers of high-rise buildings taller than 150m in Ho Chi Minh City, Viet Nam

Table 1. High-rise buildings taller than $150 \mathrm{~m}$ in Ho Chi Minh City.

\begin{tabular}{lcc}
\hline Building name & $\begin{array}{c}\text { Height } \\
(\mathrm{m})\end{array}$ & $\begin{array}{c}\text { Year } \\
\text { completed }\end{array}$ \\
\hline Bitexco Financial Tower & 262 & 2010 \\
Petroland Tower & 155 & 2011 \\
Dragon City HAGL 2 & 153 & 2012 \\
Dragon City HAGL 1 & 153 & 2012 \\
Times Square & 164 & 2012 \\
The Everrich 2 Block C & 152 & 2014 \\
Pearl Plaza & 153 & 2015 \\
Vietcombank Tower & 206 & 2015 \\
Vinhomes Central 3 & 168 & 2016 \\
Vinhomes Central 2 & 168 & 2016 \\
Vinhomes Park 3 & 151 & 2017 \\
Vinhomes Landmark 6 & 161 & 2017 \\
Vinhomes Park 7 & 168 & 2017 \\
Vinhomes Park 5 & 168 & 2017 \\
Vinhomes Landmark 1 & 168 & 2017 \\
Vinhomes Landmark 5 & 178 & 2017 \\
Vinhomes Landmark 4 & 178 & 2017 \\
Vinhomes Landmark 3 & 178 & 2017 \\
Vinhomes Landmark 2 & 178 & 2017 \\
Vinhomes Park 6 & 184 & 2017 \\
Saigon Centre Tower 2 & 194 & 2017 \\
Vinhomes Park 4 & 154 & 2018 \\
Vinhomes Aqua 3 & 160 & 2018 \\
Vinhomes Luxury 6 & 175 & 2018 \\
Vinhomes Landmark Plus A & 178 & 2018 \\
Vinhomes Aqua 2 & 184 & 2018 \\
Vinhomes Aqua 1 & 184 & 2018 \\
Vincom Landmark 81 & 461 & 2018 \\
Sunwah Pearl B2 & 164 & 2020 \\
Sunwah Pearl B1 & 170 & 2020 \\
\hline Emporis, 2021) & &
\end{tabular}

(Emporis, 2021)

\section{CASES HISTORIES}

A piled raft foundation in the subsoil has been applied successfully to many high-rise buildings projects around the world, as shown in Table 2.

From Table 2, the effectiveness of a piled raft foundation is clearly indicated by the load share between the piles and the raft based on this concept.

Table 2. Piled raft foundation - case histories[10]

\begin{tabular}{|c|c|c|c|c|c|}
\hline \multirow[t]{2}{*}{ Tower } & \multirow{2}{*}{$\begin{array}{c}\text { Structure } \\
\text { (height/sto } \\
\text { ries) }\end{array}$} & \multicolumn{2}{|c|}{$\begin{array}{c}\text { Load } \\
\text { share (\%) }\end{array}$} & \multirow{2}{*}{$\begin{array}{l}\text { Instr } \\
\text { ume } \\
\text { ntati } \\
\text { ons }\end{array}$} & \multirow{2}{*}{$\begin{array}{c}\text { Settle } \\
\text { ment } \\
\mathrm{S}_{\max } \\
(\mathrm{mm})\end{array}$} \\
\hline & & Piles & Raft & & \\
\hline $\begin{array}{l}\text { Messe-Torhaus, } \\
\text { Frankfurt }\end{array}$ & $\begin{array}{l}\text { 130m, 30- } \\
\text { storey }\end{array}$ & 75 & 25 & Yes & N.A. \\
\hline $\begin{array}{l}\text { Messeturn, } \\
\text { Frankfurt }\end{array}$ & $\begin{array}{l}256 \mathrm{~m}, 60- \\
\text { storey }\end{array}$ & 57 & 43 & Yes & 144 \\
\hline $\begin{array}{l}\text { Westend 1, } \\
\text { Frankfurt }\end{array}$ & $208 \mathrm{~m}$ & 49 & 51 & Yes & 120 \\
\hline $\begin{array}{l}\text { Petronas, Kuala } \\
\text { Lampur }^{\mathrm{PF}}\end{array}$ & $\begin{array}{l}450 \mathrm{~m}, 88 \\
\text { storey }\end{array}$ & 85 & 15 & Yes & 40 \\
\hline $\begin{array}{l}\text { QV1, Perth, } \\
\text { West Autralia }\end{array}$ & 42 storey & 70 & 30 & N.A. & 40 \\
\hline $\begin{array}{l}\text { Treptower, } \\
\text { Berlin }\end{array}$ & $121 \mathrm{~m}$ & 55 & 45 & Yes & 73 \\
\hline $\begin{array}{l}\text { Sony Center, } \\
\text { Berlin }\end{array}$ & $103 m$ & N.A & N.A & Yes & 30 \\
\hline $\begin{array}{l}\text { ICC, Hong } \\
\text { Kong }^{\mathrm{PF}}\end{array}$ & $\begin{array}{l}490 \mathrm{~m}, 118 \\
\text { storey }\end{array}$ & $70^{\mathrm{D}}$ & $30^{\mathrm{D}}$ & N.A. & N.A. \\
\hline $\begin{array}{l}\text { Commerzbank, } \\
\text { Frankfurt }^{\mathrm{PF}}\end{array}$ & $300 \mathrm{~m}$ & 96 & 4 & Yes & 19 \\
\hline $\begin{array}{l}\text { Skyper, } \\
\text { Frankfurt }\end{array}$ & $153 \mathrm{~m}$ & 63 & 27 & Yes & 55 \\
\hline
\end{tabular}

In the 1980s, the first piled raft foundation was applied in Germany to the Messe-Torhaus and Messeturm Buildings, both located in the fairground area of the city of Frankfurt am Main. The measurement of load-settlement in the MesseTorhause building showed that the shared load by the raft reached $20 \%$ and the settlement was equal to $160 \mathrm{~mm}$. In the Messeturm building, a piled raft was chosen to reduce settlement and especially the risk of excessive tilting due to inhomogeneous Frankfurt clay subsoil. The settlement was $120 \mathrm{~mm}$ and the load share taken up by the raft was $45 \%$ based on monitoring the load-settlement in this building [1].

The demand for high-rise buildings in Germany is increasing with the need for office space. Therefore, many high-rise buildings have been built using a piled raft foundation as an effective method. The success of settlement compared to the raft foundation method [11] is shown in Fig. 2

Load share by the raft of around $20-30 \%$ was found on the piled raft in Bangkok subsoil conditions for a building with 2-3 basement levels, allowing the number of piles to be reduced compared to the traditional design. Therefore, the piled raft method has been proposed as a cost- 
effective method. The reduced number of piles can save $0.63-1.75 \%$ of the total cost of foundation construction [12].

Measurement during the construction of the Navaminddrapobitr 84th Anniversary Building in Bangkok has a piled raft foundation that shares 10 $20 \%$ of the load [4]. The results based on the Plaxis $3 \mathrm{D}$ software were in good agreement with the measurements when the foundation was put in soft clay ground, even though the design ignored the contribution of the raft.

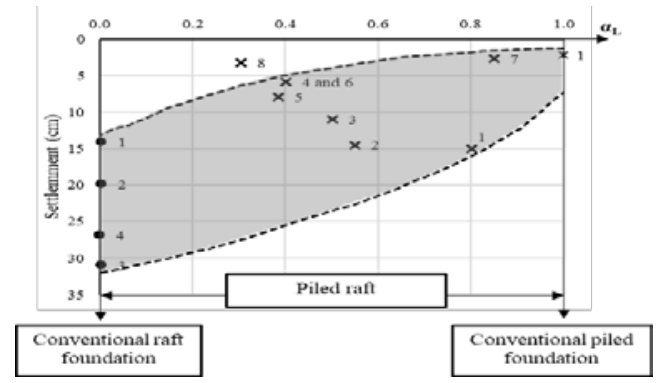

$$
\begin{aligned}
& \alpha_{\mathrm{L}}=\frac{\text { Pile load share }}{\text { Total load }} \\
& \text { Traditional raft foundation Piled raft foundation } \\
& 1 \text { = Commerz Bank (old) } \quad \mathrm{X} 1 \text { = Torhaus } \\
& 2 \text { = Dresdner Bank (old) } \\
& 3=\text { SGZ Bank } \\
& 4 \text { = Marriot Hotel (Plaza) } \\
& \mathrm{X} 2 \text { = Messeturm } \\
& \text { X3 = DG Bank } \\
& \text { X4 = Japan Center } \\
& \text { X5 = Kastor/Pollux } \\
& \mathrm{X} 6=\text { Congress Center } \\
& \text { X7 = Main Tower } \\
& \mathrm{X} 8 \text { = Eurotheum }
\end{aligned}
$$

Fig. 2 Settlement behavior of high-rise buildings in Frankfurt am Main, Germany (El-Mossallamy, 2006 [11], modified by the Author).

It is obvious that a piled raft foundation is more economic for high-rise buildings. Some foundations were designed using conventional methods as a piled foundation, but the raft in this concept can carry a part of the building.

In the past, the design of high-rise buildings in Viet Nam has been based on the piled foundation concept. The piled raft foundation has only been studied and has not been accepted under the regulations yet. In Ho Chi Minh City, load sharing by the raft is $20-21 \%$, depending on the number of piles and the limit of raft thickness to match the ultimate bending moment for optimum design [13].

\section{HO CHI MINH SUBSOIL}

Ho Chi Minh City, formerly Sai Gon, is crossed by the Sai Gon River and is the biggest city in Viet Nam in the lowlands in the south of Viet Nam. Like Bangkok and Jakarta, Ho Chi Minh City has soft soil conditions.

According to [14], the soil conditions in Ho Chi
Minh City are very complex as shown in Fig. 3 and Fig. 4. In the Metropolitan Rapid Transit (MRT) line no. 1 , the soil conditions indicate that layer 1 (very-soft-to-soft clay) occurs from the surface to $25 \mathrm{~m}$ depth in the Southwest and is thinner in the Northeast. The next layer 2 is soft-to-medium silty clay at 25 - $35 \mathrm{~m}$ from the Southwest to the middle, and the elevation of soil is higher to the Northeast. The next layer consists of medium dense, fine-tomedium sand with a thickness of $5-30 \mathrm{~m}$ in the Southwest, increasing to 35 - $55 \mathrm{~m}$ in the middle, and 10 to 55 meters in the Northeast. The last layer in this section is medium to stiff clay being $30-60$ $\mathrm{m}$ in the Southwest and $55 \mathrm{~m}$ in the middle, and the Northeast, as shown in Fig. 5.

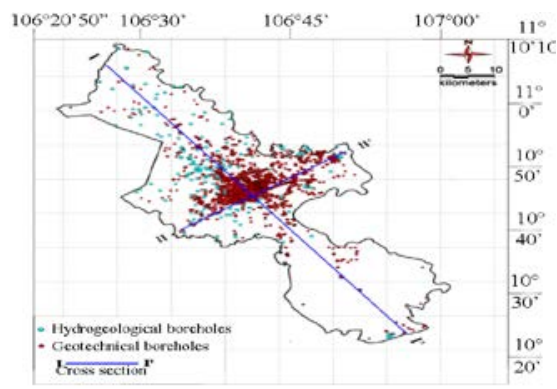

Fig. 3 Location of boreholes and profiles

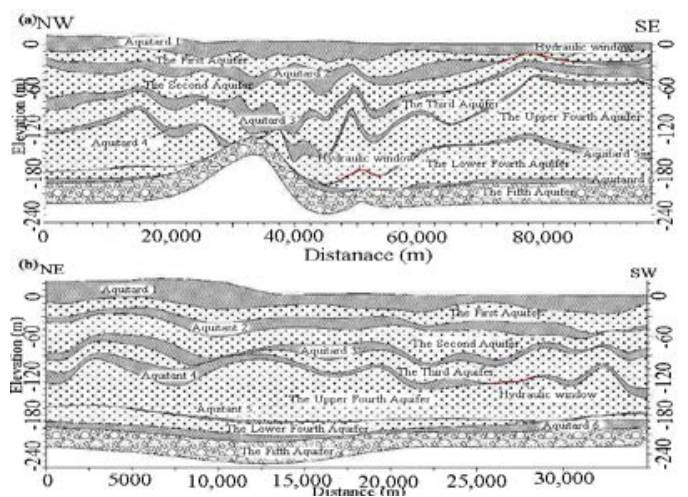

Fig. 4 Geotechnical cross-section (a) along profiles I-I'; (b) along profiles II-II'

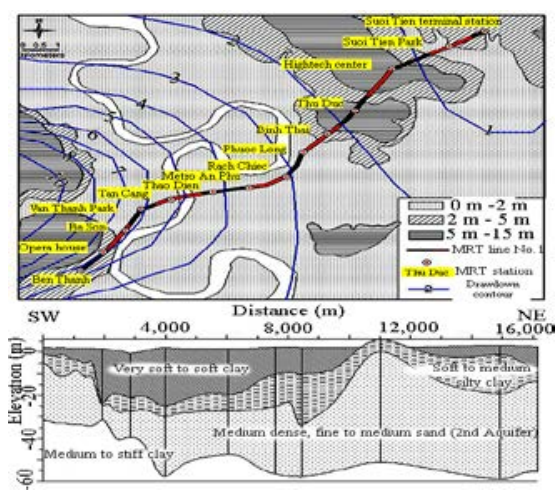

Fig. 5. Location and soil profile along MRT line no. 1, Ho Chi Minh City 
The general soft clay properties are as shown in Table 3 and are normally called Ho Chi Minh City soft clay.[15].

Table 3. Properties (average) of Ho Chi Minh soft clay in the City Central Lowlands[15]

\begin{tabular}{cc}
\hline Natural water content, $\mathrm{w}_{\mathrm{n}}$ & $80 \%$ \\
\hline Liquid limit, LL & $89 \%$ \\
\hline Plastic limit, PL & $36 \%$ \\
\hline Plasticity index, PI & 53 \\
\hline Bulk unit weight, $\gamma$ & $15 \mathrm{kN} / \mathrm{m}^{3}$ \\
\hline Specific gravity, $\mathrm{G}_{\mathrm{s}}$ & 2.68 \\
\hline Clay content & $63 \%$
\end{tabular}

\section{OUTLINE OF BUILDING PROJECT CASE STUDY}

\subsection{Outline of Building and Site Constructions}

Construction for Tower 2 in the SGR project began in 2019. The building has 18 stories and one basement floor with a gross floor area of 25,950 $\mathrm{m}^{2}$, a height of $73.7 \mathrm{~m}$, and a basement level $4.8 \mathrm{~m}$ below the ground surface. The traditional bottomup method was adopted for construction in this building.

\subsection{Design and Construction}

In this project, the bored pile had a diameter of $1.2 \mathrm{~m}$ and a length of $64.6 \mathrm{~m}$. The pile tip was at a depth of $-71.8 \mathrm{~m}$ embedded in silty fine sand with clay. Each pile cap included 2 - 4 piles, with a single pile cap being $2.4 \mathrm{~m}$ thick, with a two pile-raft in the core of the building. The pile caps were connected by tie beams and the basement floor with a thickness of $0.3 \mathrm{~m}$.

The load in the static load test was $26.45 \mathrm{MN}$ (2645 tones) equal to $230 \%$ of the pile's allowable bearing capacity.

The design was a piled foundation concept that ignored the contribution of the raft, tie beam, and basement floors. This design load included the dead load from the building and the live load carried entirely by piles. Currently, only the dead load of 295.655 MN from the structure was applied.

\section{SETTLEMENT MONITORING}

\subsection{Instrumentation}

Settlement in Tower 2 was measured at 20 locations shown in Fig. 6. The measurement activities were carried out during the construction 30 days/time during which 3 floors were built. The settlement marks were made on the toe of the core wall and column on the basement floor.

The elevation of the settlement marks was transferred from basic benchmarks. In the transfer, the distance from the machine to the target did not exceed $30 \mathrm{~m}$ and the error did not exceed $f h= \pm 0.5 \sqrt{n}$ with $n$ is the number of target stations.

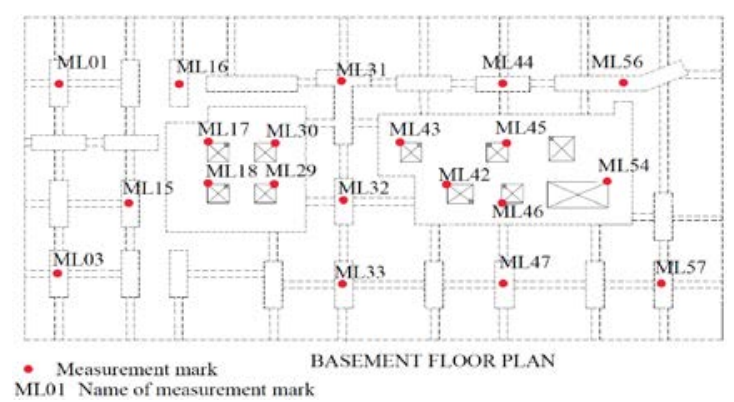

Fig. 6 Location of settlement mark

The relative settlement at each location was derived from Eq. (1) and the total settlement of each settlement mark was derived from Eq. (2)

$$
\begin{aligned}
& L_{t d}^{i}=H_{i}^{j}-H_{i-1}^{j} \\
& L_{t c}^{i}=H_{i}^{j}-H_{1}^{j}
\end{aligned}
$$

where $\mathrm{L}_{\text {tc }}^{\mathrm{i}}$ is the total settlement, $\mathrm{L}_{\text {td }}^{\mathrm{i}}$ is the relative settlement, $\mathrm{H}_{\mathrm{i}}^{\mathrm{j}}$ elevation of the settlement mark $\mathrm{j}$ in cycle $\mathrm{i}, \mathrm{H}^{\mathrm{j}}{ }_{1}$ is the elevation of the settlement mark $\mathrm{j}$ in the first cycle, and $\mathrm{H}_{\mathrm{i}-1}^{\mathrm{j}}$ is the elevation of the settlement mark $\mathrm{j}$ in the previous cycle.

\subsection{Results of Settlement Monitoring}

The contour maps of total settlement and development of total settlement are shown in Fig. 7 and Fig. 8. The settlement monitoring was done during the structure's construction period. The dead load of the building is the reason for the settlements, which were measured. In the first period from the start to the finish of casting the third floor, there was a large axial load from 2 transfer slabs on the first floor and second floors that rapidly increases the total settlement compared with other periods. In the other periods, after every 30 days, the velocity of settlement was slow with a steady increase. In the mark at the corner and edge of the raft, where the lowest settlement was at ML3, the settlement was lower than in the core of the raft. The highest settlement was at ML30, with the settlement in the final step of $16.2 \mathrm{~mm}$. The measurement showed a very small total settlement of $16.2 \mathrm{~mm}$ and a differential settlement of less than $2 \mathrm{~mm}$. These monitoring results indicated the settlement was very low. However, it showed that the pile foundation design is a conservative method because, according to [16], the allowable settlement in piled foundation design for reinforced concrete frames with reinforced concrete bracing or roof blocks or blocks and monolithic constructions in Viet Nam is 150 
$\mathrm{mm}$. The ratio of allowable settlement to the actual settlement was very high (9.3 times), so that the concept design for this building was not costeffective.

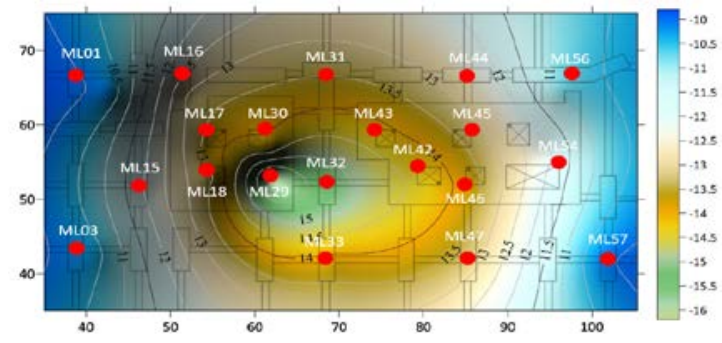

Fig. 7 Settlement contours in final step

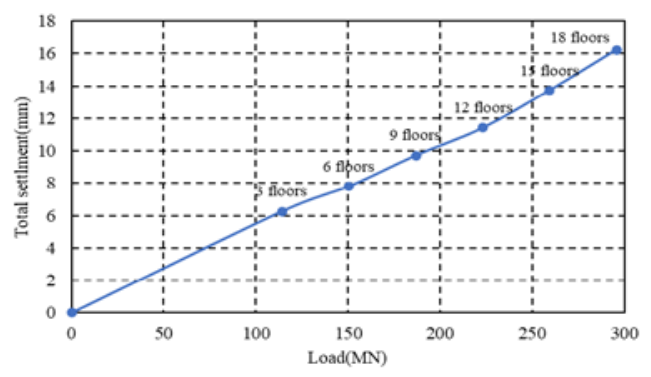

Fig. 8 Total settlement monitoring

\section{SIMPLIFIED ANALYSIS METHOD}

The simplified analysis method of PoulosDavis-Randolph (PDR) was used to evaluate the preliminary condition of the foundation and the feasibility of using piled rafts for the geology of Ho Chi Minh City, Viet Nam.

\subsection{PDR Method}

This method is similar to that described by Poulos and Davis (1980). It is a simple method for estimating load sharing between the raft and the piles, as outlined by Randolph (1994).

Using Randolph's approach, the stiffness of the piled raft foundation can be estimated, and the proportion of the total load carried by the raft can be determined using Eq. (3) and Eq. (4):

$$
\begin{aligned}
& K_{p r}=\frac{K_{p}+K_{r}\left(1-\alpha_{r p}\right)}{1-\alpha_{r p}{ }^{2}\left(K_{r} / K_{p}\right)} \\
& \frac{P_{r}}{P_{t}}=\frac{K_{r}\left(1-\alpha_{r p}\right)}{K_{p}+K_{r}\left(1-\alpha_{r p}\right)}
\end{aligned}
$$

where $K_{p r}, K_{p}, K_{r}$ are the stiffness of the piled raft, the pile group, and the raft, respectively, $\alpha_{\mathrm{rp}}$ is the raft - pile interaction factor, $\mathrm{P}_{\mathrm{r}}$ is the load carried by the raft, and $\mathrm{P}_{\mathrm{t}}$ is the total applied load.

The raft-pile interaction factor $\alpha_{\mathrm{rp}}$ can be estimated using Eq. (5)

$$
\alpha_{r p}=\frac{1-\ln \left(r_{c} / r_{0}\right)}{\zeta}
$$

where $r_{c}$ is the average radius of the pile cap, $r_{0}$ is the radius of the piled, $\zeta=\ln \left(r_{m} / r_{0}\right)$ is a measure of the radius of influence of pile, $\xi=G_{L} / G_{B}$ is the ratio of end-bearing for end-bearing piles, $\rho=G_{a v} / G_{L}$ is the heterogeneity of soil modulus, $r_{m}=\{0.25+\xi[2.5 \rho(1-v)-0.25] L)$ is the maximum radius of influence, $v$ is Poisson's ratio of soil, $L$ is the pile length, $G_{L}$ is soil shear Young's modulus at the level of the pile tip, $G_{B}$ is soil shear Young's modulus of the bearing stratum below the pile tip, and $G_{a v}$ is the average soil shear Young's modulus along the pile shaft.

The settlement can be estimated using Eq. (6) and Eq. (7):

$$
\begin{aligned}
& \text { If } \mathrm{V} \leq \mathrm{V}_{\mathrm{A}}: S_{p r}=\frac{V}{X K_{p i}\left(1-\frac{R_{f p} \beta_{p} V}{V_{p u}}\right)} \\
& \text { If } \mathrm{V}>\mathrm{V}_{\mathrm{A}}:_{S_{p r}}=\frac{V_{A}}{X K_{p i}\left(1-R_{f p}\right)}+\frac{V-V_{A}}{K_{r i}\left[1-R_{f r} \frac{\left(V-V_{p u}\right)}{V_{r u}}\right]}
\end{aligned}
$$

where $X=\left[1-0.6\left(K_{r} / K_{p}\right)\right] /\left[1-0.64\left(K_{r} / K_{p}\right)\right]$; $\beta_{\mathrm{p}}$ is the proportion of load carried by the piles; $\mathrm{V}_{\mathrm{A}}$ is applied load with the pile capacity mobilized; $V_{\text {ru }}$ and $V_{\text {pu }}$ are the ultimate capacity of the raft and the piled, respectively, and $\mathrm{R}_{\mathrm{fp}}, \mathrm{R}_{\mathrm{fr}}$ are hyperbolic factors for the pile and raft, respectively.

\subsection{Application to Current Project}

Based on the PDR theory and the modified worksheet created by Dr. Punlop Visudmedanukul, the total settlement, and load share between raft and piles on the piled raft foundation of a high-rise building in Ho Chi Minh, Viet Nam was determined.

Based on the theory of [17], the raft thickness for the whole building was equivalent to Eq. (8), namely, $1.22 \mathrm{~m}$. The foundation profile and the parameters of the soil are shown in Fig. 9 and Table 4 , respectively.

$$
d=\frac{h_{1} w_{1}+\left(h_{1}+h_{1}\right) w_{2}}{w_{1}+w_{2}}
$$

where the parameters are as shown in Fig. 10 
Table 4 Input parameters

\begin{tabular}{lcc}
\hline Parameter & Value & Unit \\
\hline Poisson's Ratio $(v)$ & 0.3 & - \\
Young's modulus $\left(\mathrm{E}_{0}\right)$ & 16 & $\mathrm{MPa}$ \\
Young's modulus $\left(\mathrm{E}_{\text {avg }}\right)$ & 146 & $\mathrm{MPa}$ \\
Young's modulus $\left(\mathrm{E}_{\mathrm{L}}\right)$ & 210 & $\mathrm{MPa}$ \\
Young's modulus $\left(\mathrm{E}_{\mathrm{B}}\right)$ & 210 & $\mathrm{MPa}$ \\
Raft thickness $\left(\mathrm{R}_{\mathrm{t}}\right)$ & 1.22 & $\mathrm{~m}$ \\
Raft Area $(\mathrm{S})$ & 2423.5 & $\mathrm{~m}^{2}$ \\
Pile diameter $\left(\mathrm{D}_{\mathrm{p}}\right)$ & 1.2 & $\mathrm{~m}$ \\
Pile length $(\mathrm{L})$ & 64.4 & $\mathrm{~m}$ \\
Number of piles $(\mathrm{n})$ & 90 & $\mathrm{piles}$ \\
Pile spacing $\left(\mathrm{S}_{\mathrm{p}}\right)$ & 4.45 & $\mathrm{~m}$ \\
\hline
\end{tabular}

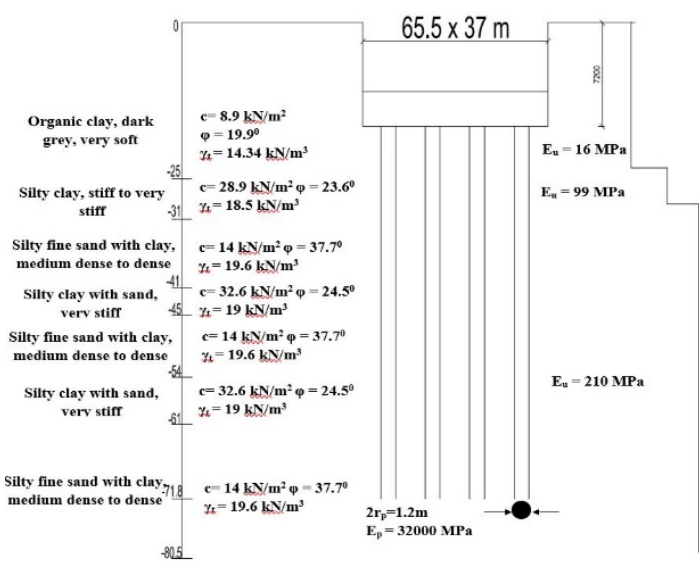

Fig. 9 Model of piled raft and profile

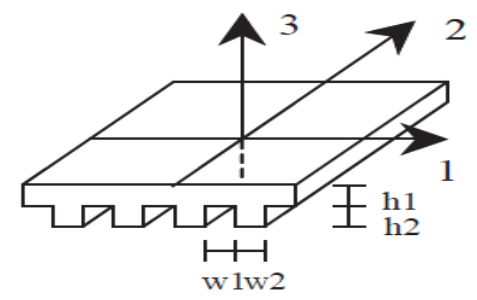

Fig. 10 Concrete floor with T-shape [17]

The compared load-settlement in each period between the measurement settlement and simplified analysis were in good agreement, as shown in Fig. 11. This proved that the simplified analysis method could effectively evaluate the preliminary condition of the foundation and settlement, and the feasibility of using a piled raft for the geology in Ho Chi Minh City, Viet Nam. On the other hand, the settlement of the simplified analysis method was very small. In the final building period for the structure, the settlement was equal to $18.6 \mathrm{~mm}$, which showed that the foundation type could be used for this building, but it is not a cost-effective method for this project because the ratio between the allowable settlement and the actual settlement was so high, at around 8.1 times.

The simplified analysis showed that the load share by the raft was $2.8 \%$, which was ignored in the design using the piled foundation concept. The comparison with foundations in Germany is shown in Fig. 12, indicating that the current project was a similar case as the Main Tower Building (X7).

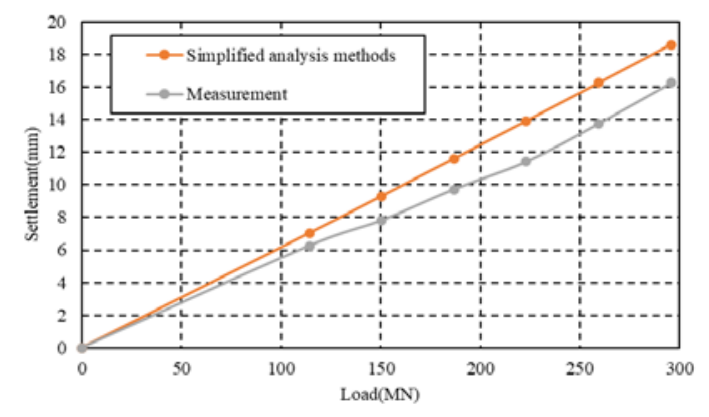

Fig. 11. Comparison between measurement and simplified analysis

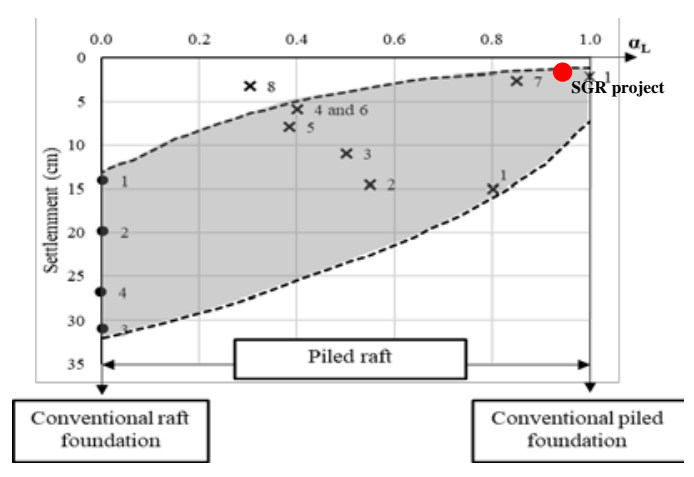

Fig. 12. Settlement behavior of high-rise buildings in Frankfurt am Main, Germany (El-Mossallamy, 2006, modified by the authors by adding SGR project)

\subsection{Parametric Study}

The behavior was evaluated of a piled raft for the foundation of a high-rise building in Ho Chi Minh City by analyzing varying the number of piles (obtaining different pile spacing), the length of piles, and embedding the raft.

Table 5 shows the geometric configurations of the piled raft that were considered in the parametric analysis. All cases had the same ground, load, and structure conditions, with a raft thickness of $1.22 \mathrm{~m}$ and a pile diameter of $1.2 \mathrm{~m}$.

Table 5. Geometric parameters analysis

\begin{tabular}{lllllll}
\hline Number of piles, $\mathrm{n}$ & $90^{*}$ & 60 & 45 & 30 & 15 & \\
\hline Pile length, $\mathrm{m}$ & $64.6^{*}$ & 48.6 & 32.2 & 16.2 & 0 \\
\hline Raft embedded, $\mathrm{m}$ & $7.2^{*}$ & 11.2 & 15.2 & 19.2 & 23.2 & 25.0 \\
\hline${ }^{*}$ Indicates design value if not varied. & & &
\end{tabular}

The settlement ratio was defined as the ratio between the settlement of a piled raft $\left(S_{\text {piled-raft }}\right)$ and an un-piled raft $\left(S_{\text {unpiled-raft }}\right)[18]$ as shown in Eq. (9): 


$$
R_{\text {total }}=\frac{S_{\text {piled-raft }}}{S_{\text {unpiled -raft }}}
$$

In the parametric analysis, with decreasing numbers of piles from 90 to 15, the settlement increased from $18.6 \mathrm{~mm}$ to $34.0 \mathrm{~mm}$, with the proportion of load share by the raft increasing from $2.8 \%$ to $5.4 \%$, as shown in Fig. 13. The settlement ratio is increased when the pile spacing/pile diameter increased, as shown in Fig. 14. For effective design, the recommended pile spacing/pile diameter should be 5 - 7 to match the optimum settlement ratio of 0.15 times the settlement of the raft, namely, $22 \mathrm{~mm}$.

Fig. 15 shows that the pile length decreased from $64.4 \mathrm{~m}$ to $16.2 \mathrm{~m}$, which was the reason for the settlement increasing from $18.6 \mathrm{~mm}$ to $132.5 \mathrm{~mm}$ and the proportion of load share by the raft increasing from $2.8 \%$ to $62.3 \%$. On the other hand, the settlement ratio decreased with increasing pile length/ pile diameter, as shown in Fig. 16. Therefore, the longer pile was most reasonable to achieve the minimal settlement ratio. However, effective foundation design minimizes not only settlement but also the cost of building. Thus, for an effective design, the recommended pile length/pile diameter was 30 .



Fig. 13 Relationship between load share by raft and total settlement with pile number

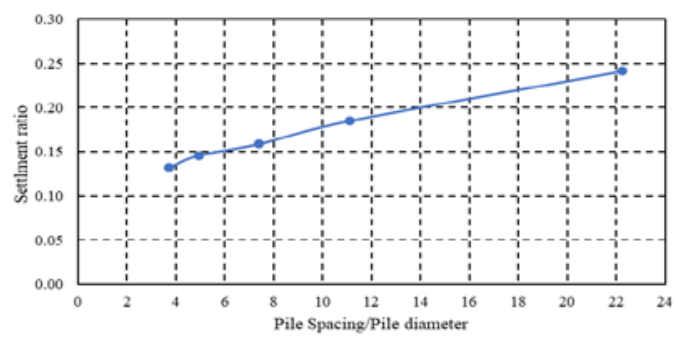

Fig. 14 Effect of number of piles (pile spacing/ pile diameter) on settlement ratio

The results from increasing the depth of the embedded raft from $7.2 \mathrm{~m}$ to $25 \mathrm{~m}$ below the ground surface are shown in Fig. 17. The load shared by the raft increased as the level of the raft increased. There was little change in the settlement when the raft was put on the first layer of soft clay. On the surface of the second layer of stiff clay at $25 \mathrm{~m}$ from the ground surface, the load carried by the raft was $30 \%$ of the applied load, where underground parking or underground shopping could be considered in future design.

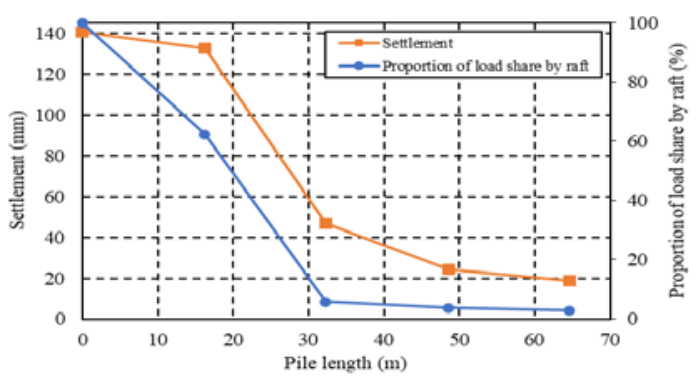

Fig. 15 Relationship between load shared by raft and total settlement with pile length

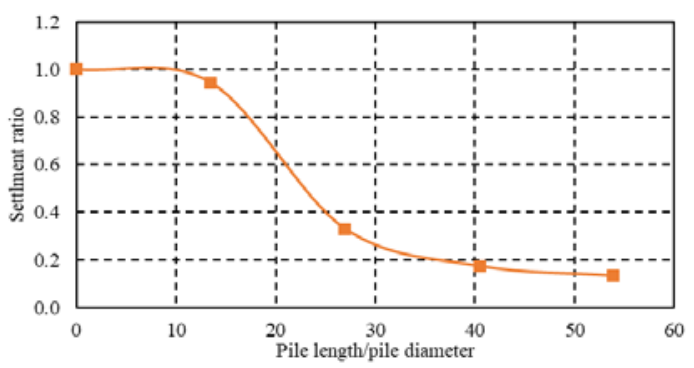

Fig. 16 Effect of pile length on settlement ratio

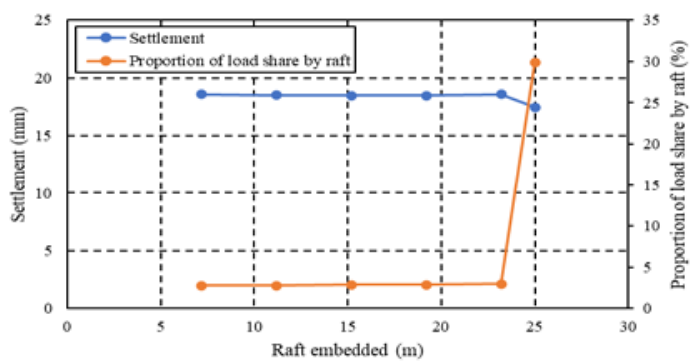

Fig. 17 Relationship between load shared by raft and total settlement with embedded raft

\section{CONCLUSIONS}

The study presented and discussed the results of settlement monitoring, parametric analysis, and applying a simplified analysis based on the PDR method to gain increased insight into the load sharing mechanism, settlement, and evaluation of the potential of using the piled raft system in Ho Chi Minh City, Viet Nam. The main conclusions were:

1) A design based on the piled foundation concept in this building was used, in which the total and differential settlement from monitoring is very small as $16.2 \mathrm{~mm}$, less than $2 \mathrm{~mm}$, respectively. Then, the piled foundation concept in this project is 
conservative. The ratio of allowable to actual settlement was 9.3 times, making the design safe but not cost effective.

2) Based on the simplified method, the load share by the raft was $2.8 \%$, which was ignored in the traditional design. The settlement results were in good agreement with the monitoring results. This proved that the method was suitable for evaluating the preliminary conditions of the foundation and settlement, and the feasibility of using a piled raft for the geology in Ho Chi Minh City, Viet Nam.

3) The load shared by the raft increased from $2.8 \%$ to $5.4 \%$ when the number of piles was reduced from 90 to 15 . The settlement ratio increased when the pile spacing/pile diameter increased, the pile spacing/pile diameter being 5-7 times, which was recommended for effective design. By reducing the length of the piles, the settlement increased, and the proportion of the load shared by the raft increased. Furthermore, decreasing the pile length/ pile diameter increased the settlement ratio, and the pile length of 30 times the pile diameter was a good choice for effective design. In addition, the raft was positioned in the second layer, could carry $30 \%$ of the applied load.

Thus, a piled raft foundation is an effective method and should be considered for high-rise buildings in Ho Chi Minh City, Viet Nam.

\section{ACKNOWLEDGMENTS}

This research was funded by the Department of Civil Engineering, and the Faculty of Engineering at Kamphaeng Sean, Kasetsart University, Thailand

\section{REFERENCES}

[1] Katzenbach R., Arslan U. and Moormann C., Piled Raft Foundation Projects in Germany. H. J.A. (Ed.), Design applications of raft foundations, 2000: p. 323-391.

[2] Barker R.M. and Puckett J.A., Load and Resistance Factor Design (Lrfd) for Highway Bridge Substructures-Reference Manual and Participant Workbook. 2001: U.S. Department Publication of Transportation.

[3] Amornfa K., Pheinwej N. and Kijpayuck P., Current Practice on Foundation Design of HighRise Buildings in Bangkok, Thailand. Lowland Technology International, 2012. 14: p. 70-83.

[4] Watcharasawe K., Jongpradist P., Kitiyodom P. and Matsumoto T., Measurements and Analysis of Load Sharing between Piles and Raft in a Pile Foundation in Clay. Geomechanics and Engineering, 2021. 24: p. 559-572.

[5] Watcharasawe K., Kitiyodom P. and Jongpradist P., 3-D Numerical Analysis of Consolidation Effect on Piled Raft Foundation in Bangkok Subsoil Condition. International Journal of GEOMATE, 2017. 12(31).

[6] Hoang L. and Matsumoto T., Time-Dependent Behaviour of Piled Raft Foundations on Saturated Clay: Experimental Investigations. International Journal of GEOMATE, 2020. 18(66).

[7] Burland J.B., Broms B.B. and Mello V.F.B.d., Behaviour of Foundation and Structures. 9th International Conference on Soil Mechanics and Foundation Engineering, 1977: p. 495-546.

[8] Clancy P. and Randolph M.F., An Approximate Analysis Procedure for Pile Raft Foundation. International Journal for Numerical and Analytical Methods in Geomechanics, 1993. 17: p. 849-869.

[9] Nguyen T.B., Samsura D.A.A., van der Krabben E. and Le A.-D., Saigon-Ho Chi Minh City. Cities, 2016. 50: p. 16-27.

[10]Long P.D., Pile Raft a Cost-Effective Foundation Method for High Rises. Geotechnical Engineering Journal of the SEAGS \& AGSSEA 2010. 41: p. 1-12.

[11]EL-Mossallamy Y.M., EL-Nahhas F.M. and Essawy A.S., Innovative Use of Piled Raft Foundation to Optimize the Design of HighRise Buildings, in The 10th Arab Structural Engineering Conference. 2006: Kuwait.

[12]Amornfa K., Analysis of Piled Raft Foundation with Their Application to Bangkok Subsoil Condition, in Engineering and Technology. 2012, Asian Institute of Technology: Thailand.

[13]Nguyen T., Le P. and Tran V., The Influence of Raft Thickness on the Behaviour of Piled Raft Foundation, in 5th International Conference on Green Technology and Sustainable Development. 2020, IEEE: Da Nang, Viet Nam. p. 483-488.

[14]Thoang T.T. and Giao P.H., Subsurface Characterization and Prediction of Land Subsidence for Hcm City, Vietnam. Engineering Geology, 2015. 199: p. 107-124.

[15]Hung N.K. and Phienwej N., Practice and Experience in Deep Excavations in Soft Soil of Ho Chi Minh City, Vietnam. KSCE Journal of Civil Engineering, 2015. 20(6): p. 2221-2234.

[16]Tcvn 10304: 2014 Pile Foundations - Design Standards.

[17]Plaxis bv P.O. Box 572 A.D., Netherlands, Plaxis 3d Manual-Material Models Manual. 2020: Netherlands. p. 1-26.

[18]Mali S. and Singh B., Behavior of Large PiledRaft Foundation on Clay Soil. Ocean Engineering, 2018. 149: p. 205-216.

Copyright (C) Int. J. of GEOMATE All rights reserved, including making copies unless permission is obtained from the copyright proprietors. 